\title{
Institutionalising a Whistle blowing Culture within Higher Education Institutions: Policy and Procedure Underpinning Good Governance at the Durban University of Technology
}

\author{
N Dorasamy \\ Durban University of Technology KwaZulu Natal, South Africa \\ nirmala@dut.ac.za
}

\begin{abstract}
The article proposes to explore the importance of policy and procedure as an impetus for establishing a whistle blowing culture. It can be suggested that the institutionalization of a whistle blowing culture through established and practiced policies and procedures can lead to lower levels of perceived retaliation, which is frequently a deterrent in blowing the whistle. The quantitative research method was employed to determine the extent to which higher education institutions implement policies and procedures to institutionalize whistle blowing as an imperative for an ethical organizational culture, which encourages potential whistleblowers to report on wrongdoing. A conceptual framework informed by legislation, policy and procedures was used to determine employee perceptions relating to the role of whistle blowing policies and procedures within the Durban University of Technology as an impetus for establishing a whistle blowing culture. The investigation was based on empirical research conducted at the Durban University of Technology, South Africa and literature on whistle blowing. In the light of the research, recommendations are made relating to institutional whistle blowing policies and procedures. The empirical findings reveal that whistle blowing legislation is inadequate to encourage whistle blowing. The article provides a comprehensive framework for the institutionalization of whistle blowing within the organizational culture as an imperative to encourage disclosure of unethical practices.
\end{abstract}

Key words: Whistle blowing, legislation, higher education, policies, procedures, organizational culture

\section{Introduction}

The imperatives and ethics of higher education and education in general cannot be compromised in view of the high costs that accrue to government because of unethical conduct. Whistle blowing is often considered as an effective mechanism to eliminate unethical conduct. Despite the protection accorded to whistleblowers through legislation like the Protected Disclosures Act 2000 in South Africa, potential whistleblowers are generally dissuaded from blowing the whistle because of the fear of retaliation. While higher education institutions may offer protection via the Protected Disclosures Act 2000, they should further institutionalize a whistle blowing culture as an important condition for effective whistle blowing. This imperative arises from the culture of fear of retaliation which is common within many higher education institutions where there are higher degrees of self- determination, which is scarce at the primary level (Vinten, 1999). It can be argued that the failure to engender a culture that supports whistle blowing as part of sound higher education governance will not perpetuate valid and constructive whistle blowing. An organizational culture which supports whistle blowing through institutionalized policies and procedures can have a positive influence on potential whistleblowers. "Lived" whistle blowing policies and practices which condemn retaliation, while promoting whistle blowing can contribute to not only exposing unethical conduct, but also act as a vital deterrent for future contemplations thereof. In view of higher education institutions having the responsibility for investigating whistle blowing reports and managing whistle blowing, it becomes necessary to investigate how it is being managed within such institutions. This will assist in determining whether the organisational culture is conducive to whistle blowing, and if not identify ways in which the organisational culture can be strengthened to support whistle blowing as a reinforce of good governance. Failure to blow the whistle can be costly to organizations. These large costs show the need for organizations to rigorously monitor those engaging in unethical practices in organizations. Further, Miceli, Near and Dworkin (2008) stated that whistle blowing is the most valuable approach in revealing unethical conduct compared to other mechanisms like external audits and internal controls. In African countries, like South Africa, where corruption is a common and routine element of the functioning of administrative systems, employees are not reporting unethical conduct because of the fear of retaliation. Therefore, the protection accorded to whistleblowers through legislation must be effective in encouraging potential whistleblowers to disclose unethical conduct. In this regard, organizations must institutionalize policies and procedures that reflect the practice of ethics. It can be argued that when organizations are perceived by their employees as having a 
strong ethical outlook, it can be influential in motivating employees to blow the whistle. Therefore, the organizational culture is important to understand effective whistle blowing. In this regard, an organisational culture that regularly articulates and communicates policies and procedures, underpinned by evidence of "walking the talk" can be instrumental in encouraging whistle blowing without fear of retaliation.

\section{Literature Review}

Whistle blowing culture: Whistle blowing, perpetuated by concerns around high levels of corruption around the world, is dependent not only on legislation, but also on commitment to and enactment of high standards of ethics to influence the disclosure of unethical conduct. Whistleblowers, who are employees who expose unethical conduct within their organizations, generally disclose wrongdoing at a great personal and professional risk (Dryburgh, 2009). Whistle blowing is encouraged in organizations where public interest is maintained; individual conscience and criticisms are tolerated; and "principled dissent" is condoned because it promotes basic values like loyalty, integrity and honesty. This perpetuates a culture within organizations whereby employees have shared beliefs on ethical standards. Since an organization is a social entity, which motivates and influences employee conduct, the organizational culture must reflect values that shape the conduct of employees if it is to exemplify the elements supporting whistle blowing (Werner, 2008). Zhang, Chiu and Wei (2009) contend that an organizational ethical culture, which provides collective norms for management endorsed conduct, significantly improves the expected effectiveness of the intentions of potential whistleblowers. It can be suggested that an ethical culture is positively related to whistle blowing intent, since employees who perceive a relataliatory environment are much less likely to be whistleblowers (Miceli et al., 2008). According to Chen, Sawyers and Williams (1997), any endeavour to increase ethical standards and to decrease unethical conduct should concentrate on the organisation and its culture. In this regard, the ability to see the organization as being ethical may be related to the attributes of the organizational culture rather than to the attributes of individual employees. Vinten (1999) referred to higher education institutions where cases of unethical conduct were reported, but management did not respond to the reports because of a poor whistle blowing culture within such institutions. Lewis, Ellis, Kyprianou and Homewood (2001) indicated that there were three main reasons cited by respondents from higher education institutions as to why whistle blowing policies and procedures were introduced: good practice, compliance with the law and management initiative. Further, the majority of respondents indicated that they were happy with procedures that were monitored (Lewis et al., 2001). In a study by Pillay, Dorasamy and Vedran (2012), it was revealed that if organizations show respect for rules and obligations and are concerned with the welfare of everyone, then employees in abiding by the policy of the organization could be motivated to blow the whistle.

An organizational culture which shows zero tolerance toward unethical conduct can be influential in shaping the perceptions of employees of the seriousness of the misconduct. Therefore, values which uphold ethical conduct must be communicated and practiced within organizations. This re-enforces awareness on ethical practices. In this regard, Bhasin (2010) argues that organizational culture can be strengthened by prioritizing positive values through routine practice. Similarly, awareness of whistle blowing must be frequently raised, so that ethical conduct is not under-prioritized. Since employees are generally the first to identify unethical conduct in the workplace, the organizational culture must be conducive for the disclosure of such wrongdoing. Since whistle blowing to the media is frowned upon and disclosure only to recognized agencies is given protection, whistleblowers need to feel confident and safe that blowing the whistle in good faith would lead to a focus on the message and not the messenger (Dorasamy and Pillay, 2011). Therefore, a culture-supporting whistle blowing should be shared and "lived" throughout the organization. While legislation is an imperative, it should not be seen as a panacea in and of itself. It is an important consideration, that despite legislative protection, employees expect evidence of guarantees from their employers against retaliation, if their confidence in internal disclosures is to be maintained. Once employees perceive adverse employment consequences of whistle blowing, they become suspicious of organizational commitment to whistle blowing. Any form of procedural injustice to the whistleblower can lead to the withdrawal of trust and loyalty, thereby affecting the ethical culture in the organization. Therefore, by establishing ethical guidelines supporting whistle blowing, a whistle blowing culture can permeate. According to Shahinpoor and Matt (2007), organizations that value "organizational fit", are not tolerant toward non-conformity to organizational ideologies. In such organizations, questioning is often perceived as disloyal and those who challenge the status quo are generally dealt with punitively. Such an organizational culture values conformity to organizational policy 
which does not promote whistle blowing. Whistleblowers in such organizations can be seen as standing apart from the organization and its practices. Therefore, an organizational culture which does not promote whistle blowing should not force employees to assume the organizational persona, thereby becoming enemies of their own personal values.

Some of the features of an organizational culture that promotes whistle blowing include (Shahinpoor and Matt, 2007):

- Recognition of personal dignity.

- Humanization of individuals.

- Prioritizing working toward the common good as reflected in the organization's mission statement.

- Development of a learning environment which emphasizes loyalty, constructive criticism and competence.

- $\quad$ Right to have a voice, act freely and be taken seriously as an individual of conscience.

The aforementioned features arguably enjoy ethical benefits that flow to both employees and the organization. The recognition of core values like integrity, loyalty and dignity illustrates to employees that unethical conduct is not tolerated. Such organizations can be considered as efficient, effective and rational in exposing unethical conduct. Bowditch and Bouno (2001) state that a strong culture-promoting whistle blowing can significantly influence the conduct of employees in several ways. Higher levels of shared values have a greater impact on the organizational culture, results in less ambiguity about the significance of different assumptions and are powerful in guiding the conduct of employees. Therefore, higher levels of shared values can make a significant contribution in not only providing guidance for ethical conduct, but also acting as a yardstick to expose unethical conduct (Werner, 2008). In this regard, Werner (2008) considers widely accepted and shared beliefs as being instrumental in entrenching a dominant organizational culture where enacted values are actually exhibited or converted into employee conduct. Such enacted values are conducive to whistle blowing, without fear of retaliation. Since everyone is expected to "walk the talk", there is more reinforcing information about what constitutes ethical conduct. Further, when there is greater direction in terms of share values, higher levels of commitment to whistle blowing, without fearing occupational detriment, can be achieved. A whistle blowing culture affects all aspects of organizational life such as organizational policies and procedures. Organizational commitment to ethical conduct, through the establishment and enactment of policies and procedures, can be a driver of employee ethical conduct and organizational effectiveness.

Whistle blowing policy and procedures: Whistle blowing, as an important component of ethical conduct, should be developed and institutionalized through actions. Policies and procedures should lay the foundation for employee conduct that supports what is good for the individual and what is good for the organization. Employee actions, like whistle blowing, can be encouraged when a whistle blowing culture relating to justice within the organization is dominant. In this regard, a study by Pillay and Dorasamy (2011) indicated that legislation alone did not suffice as enough protection for the whistleblower, as the best protection for a whistleblower is being part of an organizational culture which encouraged disclosures to be made in accordance with whistle blowing policies and procedures. It can be suggested that the right type of culture which has a whistle blowing system institutionalized, not only accommodates the whistleblower, but also protects the whistleblower against possible retaliation. According to Vuuren (2008), it cannot be assumed that employees will be naturally ethical or prone to behave ethically. It is possible that genuinely ethical employees will unknowingly commit wrongdoing, while others may wilfully behave unethically. Therefore, legislation has to be complemented by organizational policies and procedures that set standards to guide employees. This reinforces legitimate behaviour sanctioned by the organization, while enhancing the efficacy of whistle blowing. Hellreigel, Slocum and Woodman (1998) identified important reinforces within the organizational culture which can provide an important impetus for whistle blowing: management focus on what is important and expected, identification of strategies to continuously strengthen an ethical culture, role modelling by management reiterate ethical messages and the establishment of a reward and punishment system that publicizes organizational priorities and values.

The reinforces can promote a whistle blowing culture, thereby motivating potential whistleblowers to disclose unethical practices. The Ethics Resource Centre (2007) reported that 61 percent of employees report misconduct in organizations with comprehensive ethics programmes, while only 35 percent of employees report wrongdoing in organizations with minimal ethics programmes. This is further 
supported by Lewis et al. (2001) who advocate that the more mechanisms that are used to communicate the existence of policies and procedures, the more likely that potential whistleblowers will be aware of it. Also, it is important that such mechanisms should not only be geared toward those that deal with the whistle blowing reports, but also those who make disclosures of unethical conduct. It can therefore be argued that the exhibition of whistle blowing policies and procedures as a component of organizational commitment to ethical conduct can make a significant contribution to compliance, enforceability, accountability and responsibility among employees. Bhasin (2010) further states that once employees perceive policies and procedures as reflecting democratic cultural values guiding organizational activities, then whistle blowing intent can increase. In this regard, Pillay and Dorasamy (2011) argue that the following imperatives can show that whistle blowing is prioritized within the organization as an open and transparent endeavour: keeping the whistleblower informed of the status of the inquiry, fully explaining the investigative process to the whistleblower, information sharing regarding why some allegations are not investigated and the possibility that some allegations may result in long term system changes rather than immediate disciplinary action.

Table 1: Mean Scores

\begin{tabular}{|c|c|c|}
\hline Good Governance & Mean & Std. Dev \\
\hline Unethical practices that are not investigated reflect a poor organization Culture. & 4.4957 & 0.83691 \\
\hline $\begin{array}{l}\text { The institutional culture shows a strong adherence to ethical values and } \\
\text { practices. }\end{array}$ & 2.7436 & 1.14586 \\
\hline There is explicit top management support for whistle blowing. & 2.6154 & 1.1207 \\
\hline There is an institutional approved policy for the protection of whistleblowers. & 2.4615 & 1.1106 \\
\hline $\begin{array}{l}\text { Retaliation from senior management and colleagues is highly likely if I blow the } \\
\text { whistle. }\end{array}$ & 3.3419 & 1.23987 \\
\hline $\begin{array}{l}\text { The whistleblowers line investigates any information received on unethical } \\
\text { practices. }\end{array}$ & 2.5641 & 1.13247 \\
\hline $\begin{array}{l}\text { A well-managed whistleblowers line reflects the institution's commitment to } \\
\text { good governance. }\end{array}$ & 4.1795 & 1.0223 \\
\hline The whistle blowing line has encouraged the disclosure of unethical practices. & 2.641 & 1.24887 \\
\hline The whistle blowing line has contributed to decreased unethical practices. & 2.2564 & 1.06798 \\
\hline $\begin{array}{l}\text { Employees feel confident to report unethical practices through the } \\
\text { whistleblowers line. }\end{array}$ & 2.2906 & 1.05911 \\
\hline \multicolumn{3}{|l|}{ Policy and Procedures } \\
\hline Whistle blowing should form part of an institution's culture. & 4.4274 & 0.81279 \\
\hline Employees who blow the whistle should be considered loyal. & 4.2222 & 0.98358 \\
\hline Employees will be encouraged to blow the whistle if they do not fear retaliation. & 4.4786 & 0.74969 \\
\hline An institution has a legal obligation to protect whistleblowers from retaliation. & 4.5812 & 0.80128 \\
\hline $\begin{array}{l}\text { The whistleblowers line gives employees the right to question unethical } \\
\text { practices. }\end{array}$ & 4.265 & 0.95946 \\
\hline $\begin{array}{l}\text { A well-managed whistleblower's line shows that the institution is "walking the } \\
\text { talk" in terms of high ethical standards. }\end{array}$ & 4.3761 & 0.90712 \\
\hline $\begin{array}{l}\text { Employees must be familiar with the institutional whistle blowing compliance } \\
\text { policy. }\end{array}$ & 4.547 & 0.63647 \\
\hline Employees who disclose false information should face disciplinary action. & 4.3419 & 0.96635 \\
\hline $\begin{array}{l}\text { Employees will be encouraged to blow the whistle if they have confidence in the } \\
\text { investigative ability of the whistle blowing authority at the institution. }\end{array}$ & 4.5812 & 0.76833 \\
\hline
\end{tabular}

Table 1 indicates minor standard deviations, thereby confirming that variation from the mean scores was not high. With regard to good governance, there was strong agreement that the investigation of unethical practices reflect a good organizational culture (4.49). Further, a commitment to good governance is evidenced by a well-managed whistleblowers line (4:17).

\section{Methodology}

The study was quantitative in approach, using the Durban University of Technology (DUT) as a case study. A non-probability sampling technique was used. Data for this study was collected in 2011 from employees at the Durban University of Technology, South Africa. 117 employees completed the electronically administered questionnaire. 
Measurement: An exploratory-type survey questionnaire was developed to explore employee perceptions on whistle blowing. A total of 29 questions were present and classified into four groups: respondent's demographics; legislation; governance; policy and procedure. Employee responses to whistle blowing practices were measured by asking them to evaluate statements shown in Table 1 . Respondents were asked to evaluate how strongly they agreed or disagreed with each of the given statements on a scale from 1 (strongly agree) to 5 (strongly disagree). The mean scores are reported in Table 1.

All items under policy and procedure possess a mean greater than 3.5, meaning that most respondents agree that policy and procedure are important for establishing an organizational culture conducive to whistle blowing, without a fear of retaliation. Further, the enactment of policies and procedure, relating to whistle blowing, is reflective of the institution walking the talk with respect to high ethical standards. With regard to policy and procedure, confidence in the investigative ability of the whistle blowing authority at the institution can encourage employees to blow the whistle (4.58). Further, employees view institutions as having a legal obligation to protect whistleblowers from retaliation (4.58). Further, if there is no fear of retaliation, employees will be encouraged to blow the whistle (4.47). Familiarity with the institutional whistle blowing compliance policy is important as revealed by respondents (4.54). Table 2 is a summary of the Cronbach's alpha reliability measure for the various sections that comprises this study.

Table 2: Reliability coefficients

\begin{tabular}{ll}
\hline Section & Cronbach's Alpha \\
\hline A legislative perspective & 0.701 \\
Contribution to good governance & 0.773 \\
An institutional perspective & 0.810 \\
Overall & 0.811 \\
\hline
\end{tabular}

All of the reliability scores are above the recommended norm (as per UCLA minimum requirements).This means that the respondents scored the construct in a consistent manner.

Limitations: Data collected concentrates entirely on employees within a higher education institution in a developing democratic state. Therefore, its usefulness elsewhere is limited.

\section{Results and Discussion}

\section{Whistle blowing Policy and Procedure:}

It is positive that $90.60 \%$ of employees at the DUT felt that whistle blowing should form part of an institution's culture. This is important since employees are generally the first to identify unethical conduct in the workplace. Further, a whistle blowing culture can encourage greater commitment to core values and serve as a foundation to shape conduct within the organization. When core values are pervasive throughout the organization, whistle blowing will be supported by ethical considerations recognizing the organizations condemnation of unethical conduct. Most respondents (84.62\%) agreed that employees, who blow the whistle, should be considered loyal. Loyal employees support the collective interest of the organization by strengthening the reputation of the organization. Further, it can be argued that loyal employees use their power for ethical interests and therefore expect management to respond to whistle blowing in the public's best interest. $92.31 \%$ of respondents agreed with the statement that employees would be encouraged to blow the whistle if they do not fear retaliation. While whistle blowing may be the right thing to do, employees often do not blow the whistle because of the fear of retaliation and the associated costs. By enacting zero tolerance to unethical conduct, organizations can contribute to higher levels of trust, loyalty, honesty and confidence in the organization. Employees who are exposed to such a culture will not perceive retaliation from the organization as a response to whistle blowing.

Table 3: Institutional perspective: Whistle blowing policy and procedure

\begin{tabular}{llll}
\hline Whistle blowing should from part of an institutions culture. & Disagree & Uncertain & Agree \\
Employees who blow the whistle should be considered loyal. & 4.27 & 5.13 & 90.60 \\
Employees will be encouraged to blow the whistle if they do not fear & 9.40 & 5.98 & 84.62 \\
retaliation. & & 5.13 & 92.31 \\
\hline
\end{tabular}




\begin{tabular}{|c|c|c|c|}
\hline $\begin{array}{l}\text { An institution has a legal obligation to protect whistleblowers from } \\
\text { retaliation. }\end{array}$ & 3.42 & 1.71 & 94.87 \\
\hline $\begin{array}{l}\text { The whistleblowers line gives employees the right to question unethical } \\
\text { practices. }\end{array}$ & 5.98 & 7.69 & 86.32 \\
\hline $\begin{array}{l}\text { A well-managed whistleblower's line shows that the institution is "walking } \\
\text { the talk" in terms of high ethical standards. }\end{array}$ & 5.98 & 3.42 & 90.60 \\
\hline $\begin{array}{l}\text { Employees must be familiar with the institutional whistle blowing } \\
\text { compliance policy. }\end{array}$ & 1.71 & 2.56 & 95.73 \\
\hline Employees who disclose false information should face disciplinary action. & 8.55 & 1.71 & 89.74 \\
\hline $\begin{array}{l}\text { Employees will be encouraged to blow the whistle if they have confidence } \\
\text { in the investigative ability of the whistle blowing authority at the } \\
\text { institution. }\end{array}$ & 2.56 & 1.71 & 95.73 \\
\hline
\end{tabular}

Figure 1: Institutional perspective: Whistle blowing policy and procedure

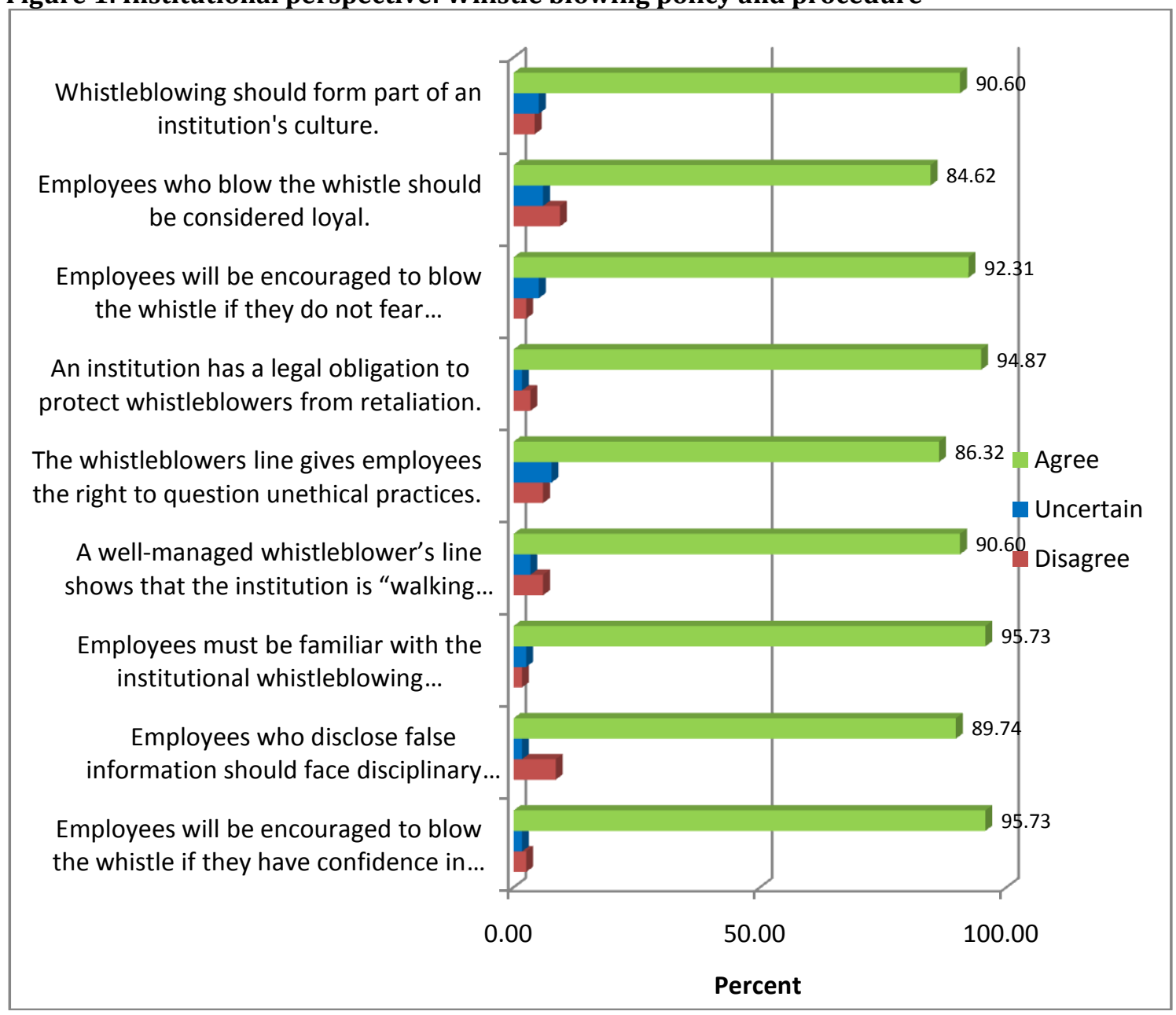

Majority of respondents (86.32\%) agreed that an institution has a legal obligation to protect whistleblowers from retaliation. Such a legal obligation not only holds the expectation of a transparent responsible and accountable management system, but also offers employees the option to disclose unethical conduct in good faith and be protected from organizational retaliation. It is positive that $90.60 \%$ of respondents believed that a well-managed whistleblower's line shows that the institution is "walking the talk" in terms of high ethical standards. A whistleblowers line reflects the responsibility of the organization to take action against unethical conduct. This can increase the probability of potential whistleblowers disclosing unethical conduct. Further, it is also an acknowledgement by the organization that every employee should uphold the highest standard of ethics. Majority of respondents (95.73\%) agreed that employees must be familiar with the institutional whistle blowing compliance policy. In this regard, awareness needs to be promoted, regarding whistle blowing policy and procedures. Employees need to understand whistle-blowing mechanisms, so that early disclosures can be made based on the understanding that the organization is committed to high ethical standards. $89.74 \%$ of respondents agreed that employees who disclose false information should face disciplinary action. This is important, 
as it would show that the organization attaches importance to the display of integrity and good faith, which is integral to the organizational culture. This is a reliable indication that the organization is conducting itself in an accountable and regulated way, thereby reinforcing confidence in the whistle blowing culture within the organization. Majority of respondents (95.73\%) felt that employees would be encouraged to blow the whistle if they have confidence in the investigative ability of the whistle blowing authority of the institution. The existence of a whistle blowing authority must be properly established and communicated to all employees. This bears testimony to the fact that the organization "walks the talk". This necessitates an integrity approach which internalizes values and standards that rely on the commitment of the organization to a set of "lived" experiences like ethics awareness training and enacted disciplinary processes for unethical practices. Whistle blowing culture

\section{Table 4: Whistle blowing culture}

\begin{tabular}{|c|c|c|c|}
\hline & Disagree & Uncertain & Agree \\
\hline $\begin{array}{l}\text { Unethical practices that are not investigated reflect a poor organizational } \\
\text { culture. }\end{array}$ & 4.27 & 4.27 & 91.45 \\
\hline $\begin{array}{l}\text { The institutional culture shows a strong adherence to ethical values and } \\
\text { practices. }\end{array}$ & 48.72 & 19.66 & 31.62 \\
\hline There is explicit top management support for whistle blowing. & 43.59 & 35.04 & 21.37 \\
\hline $\begin{array}{l}\text { There is an institutional approved policy for the protection of } \\
\text { whistleblowers. }\end{array}$ & 37.61 & 48.72 & 13.68 \\
\hline $\begin{array}{l}\text { Retaliation from senior management and colleagues is highly likely if I blow } \\
\text { the whistle. }\end{array}$ & 23.08 & 25.64 & 51.28 \\
\hline $\begin{array}{l}\text { The whistleblowers line investigates any information received on unethical } \\
\text { practices. }\end{array}$ & 38.46 & 41.03 & 20.51 \\
\hline $\begin{array}{l}\text { A well-managed whistleblowers line reflects the institution's commitment to } \\
\text { good governance. }\end{array}$ & 8.55 & 5.98 & 85.47 \\
\hline $\begin{array}{l}\text { The whistle blowing line has encouraged the disclosure of unethical } \\
\text { practices. }\end{array}$ & 40.17 & 32.48 & 27.35 \\
\hline The whistle blowing line has contributed to decreased unethical practices. & 52.14 & 39.32 & 8.55 \\
\hline $\begin{array}{l}\text { Employees feel confident to report unethical practices through the } \\
\text { whistleblowers line. }\end{array}$ & 58.97 & 30.77 & 10.26 \\
\hline
\end{tabular}

\section{Figure 2: Whistle blowing culture}

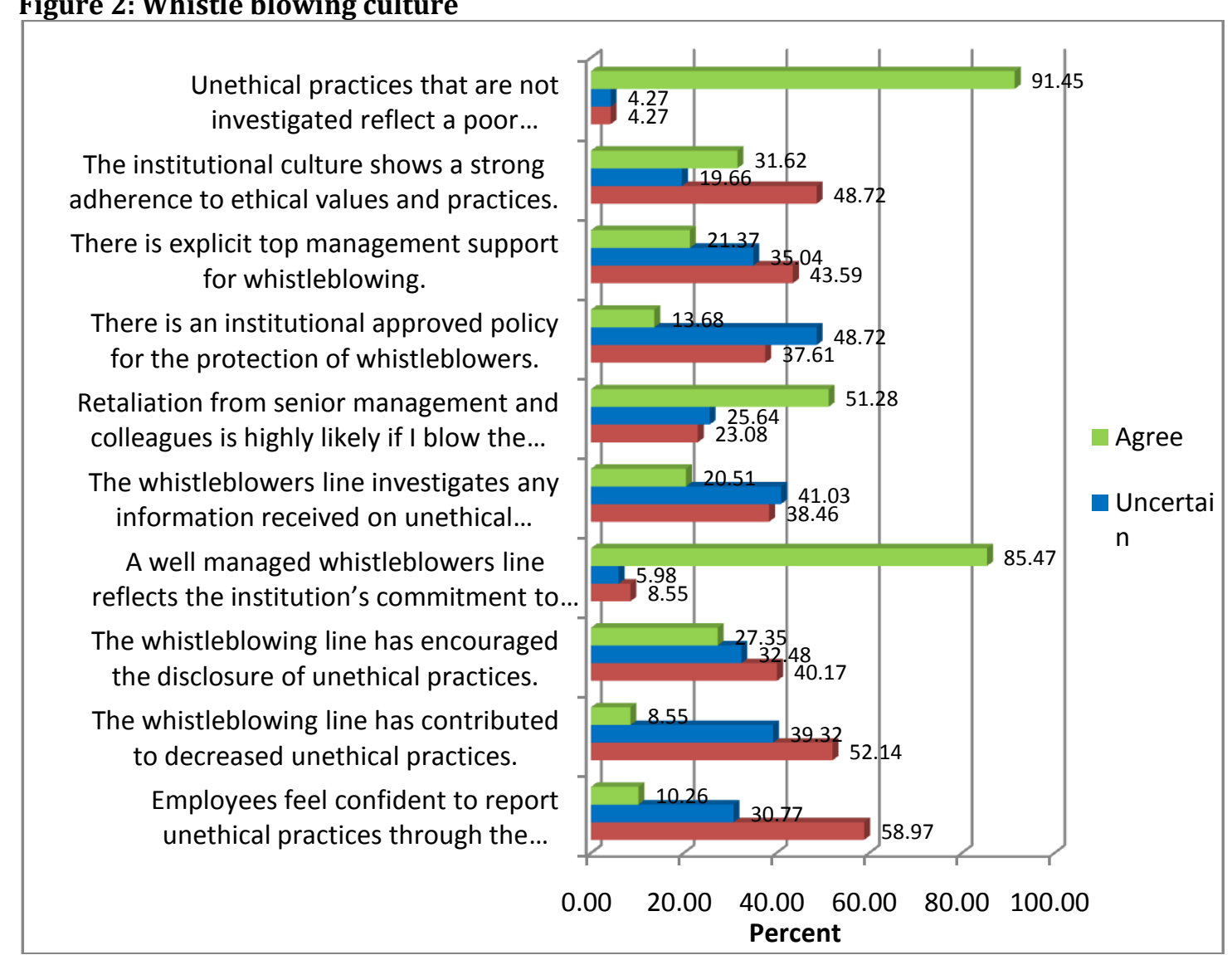


Majority of respondents (91.45) agreed that a poor organizational culture is reflected when unethical practices are not investigated. Organizations have a responsibility to contribute to the ethical dimensions of good governance. The Second King Report on Corporate Governance issued guidelines for good governance which is underpinned by ethical conduct that protects the rights of all who depend on the organization to achieve its goals (IOD, 2002). Therefore, the investigation of unethical practices shows responsible and accountable governance. $48.72 \%$ of employees agreed that the institutional culture did not show a strong adherence to ethical values and practices, which are reinforced by the lack of explicit support, from top management for whistle blowing (43.59\%). According to Kouzes and Posner (1987), ethical performance requires management to regulate core values such as altruism, commitment, integrity and transparency. In the absence of such recognition by management, a framework for good governance becomes elusive. Studies by Near and Miceli (1996) show a link between positive organization values and motivation to blow the whistle. The results show a poor adherence $(31.62 \%)$ to ethical values and practices and only $27.35 \%$ agreed that the whistleblowers line has encouraged the disclosure of unethical practices. This means that if employees perceive a strong adherence to ethical values and practices, then the whistleblowers line may probably encourage an increased disclosure of unethical practices. It is therefore important that the institution show evidence of practicing ethical values which are entrenched in goals and procedures, if it is serious about encouraging whistle blowing intent. Efficient, transparent and accountable organizations ensure that policies and procedures are not only developed, but also made "public" to employees. There was a high level of disagreement (37.61\%) and uncertainty (48.72\%) regarding an institutional approved policy for the protection of whistleblowers. This can be a possible deterrent for potential whistleblowers. Kaplan (2001) argues that initiatives like a whistle blowing policy can help to foster an environment that rewards and encourages whistle blowing. Further, low levels of awareness can impede a whistle blowing culture. Therefore, if employees are not educated about policies and procedures regarding whistle blowing then their effectiveness can be thwarted.

Despite the implementation of a whistleblowers line, 52.14\% felt that it did not contribute to decreased unethical practices, while $40.17 \%$ felt that it did not encourage the disclosure of unethical practices. It can be argued that if whistle-blowing mechanisms like a whistleblowers line is not actively promoted and practiced, then it becomes futile as a real and visible mechanism. Sullivan (2009) argues that organizations should "eat, drink and sleep" good governance. One of the ways is to practice ethical standards that extend beyond laws and regulations. This can be achieved through training programmes, regularly communicating management policies and procedures to employees and establishing monitoring processes that can expose unethical practices. An integrated approach that includes prevention, detection, investigation and resolution is integral for combating unethical practices (Dorasamy and Pillay, 2011b). Majority of the respondents (58.97\%) did not feel confident to report unethical practices through the whistleblowers line. It is therefore incumbent upon the organization to gain the confidence and trust of potential whistleblowers, so that employees can feel safe to make disclosures. The institutionalization of ethics through enacted practices of enforcement can achieve credibility, rather than merely espousing elaborate policies and procedures that fail to show evidence of commitment. This can be integral in promoting whistle blowing, rather than suppressing the messenger. A study by Zhang, Chiu and Wei (2009) showed that whistle blowing was enhanced when an organizational ethical culture promoted values endorsed by management. Further, following research by Miceli et al., (2008), it can be argued that the ethical culture conveyed within an organization affects the whistle blowing intentions of employees. The high levels of uncertainty can be indicative of a lack of awareness of issues relating to whistle blowing. It can be argued that the lack of awareness can reflect a poor whistle blowing culture. The disclosure of unethical conduct is contingent upon employees willing to blow the whistle in organizations with a culture supporting high ethical standards (Dorasamy and Pillay, 2011a).

While employees support whistle blowing being part of the organizational culture, employees believe that the organizational culture does not show a strong adherence to ethical values and practices. From the data, it is deduced that management support for whistle blowing is not explicit. This can be a significant deterrent for whistle blowing, since the lack of management support can affect the institution not walking the talk in terms of high ethical standards, poor confidence in the investigative ability of the whistle blowing authority within the institution and a poor institutional legal obligation to protect employees from retaliation. It is therefore, recommended that management should embark on organizational programmes that reflect its explicit support for whistle blowing and high ethical standards. De Maria (2005) indicated that confidence in whistle blowing agencies and in the effectiveness of managing disclosure is important to promote whistle blowing within any organization. However, the data suggests 
that employees do not feel confident to report unethical practices through the whistleblowers line and neither has the whistleblowers line encouraged the disclosure of unethical practices. Therefore, it can be suggested that whistle blowing should be prioritized as an internal control mechanism. Greater communication to create awareness and reporting on whistle blowing incidents can improve confidence in the whistleblowers line. Employees believe that a whistleblower's line gives employees the right to question unethical practices. However, while the organization has established a whistleblowers line, the data suggests that it has failed in the following ways: has not encouraged the disclosure of unethical practices, has not decreased unethical practices and employees lack the confidence to report unethical practices. This illustrates that the whistleblower's line does not adequately reflect the institution's commitment to good governance. Poor accountability, efficiency and a lack of transparency characterizes the whistle blowing culture within the organization. It is therefore imperative that management takes into account organizational priorities relating to whistle blowing so that employee disclosure is not undermined by organizational weaknesses relating to the management of whistle blowing.

In view of growing demands for an ethos of good governance, the establishment of organizational policies and procedures in accordance with legislative guidelines is inadequate. This has to be reinforced by the following (Shahinpoor and Matt, 2007):

- Maintaining public serving interests.

- Development of a learning organization that places great emphasis on competent, dignified and loyal employees.

- Support for employees to have a voice, act freely and autonomously and to be taken seriously as individuals of conscience.

- Promoting employee integrity by encouraging employees to engage in whistle blowing.

- The above features contribute toward institutionalizing a whistle blowing culture that condemns retaliation, while promoting the ethical benefits that flow to the organization.

It can be suggested that emphasizing organizational core values through action can facilitate a strong sense of identity to employees, thereby encouraging commitment to ethical practices and enhanced loyalty to organizational goals. The establishment and implementation of whistle blowing policies and procedures can be influential in advancing an organizational culture that supports whistle blowing. The enactment of such policies and procedures is important in reinforcing employee perceptions that the organization is not merely paying lip service to important values underpinning ethical conduct. More so, it can also lead to low perceptions of retaliation, since a strong ethical culture can be a "living" testimony of organizational commitment to ethical conduct.

\section{Conclusion}

Unethical conduct results in the ineffective and inefficient use of an organization's resources, while undermining confidence in the organization. Whistle blowing, as a strategy to combat unethical conduct, has to be underpinned by an integrated approach within any organization to encourage the disclosure of unethical practices. Legislation which offers protection of whistleblowers has to be complemented by policies and procedures supporting an organizational culture conducive to whistle blowing. This is not only a cornerstone of good governance, but also gives the whistleblower some assurance of protection from retaliation. The Durban University of Technology needs to strengthen its whistle blowing culture through training and development programmes to raise greater awareness among employees regarding whistle blowing practices and policies. Furthermore, there needs to be a more effective way of monitoring the effectiveness of whistle blowing mechanisms implemented at the institution if it intends to improve the confidence of potential whistleblowers. It can be suggested that communication regarding whistle blowing should become an area of focus for management. It can be suggested that if the organizational culture does not pay lip service to ethical practice, then whistleblowers can be encouraged to make disclosures. A whistle blowing culture can emerge if there is organizational support for public interest disclosure of unethical practices. 


\section{References}

Bhasin, M. (2010). Corporate governance in the Asian countries. African Journal of Business Management, 4(10), 1964-1971.

Bowditch, J. L. \& Buono, A. F. (2001). A primer on organizational behaviour, New York: John Wiley and Sons Inc.

Chen, A. Y. S., Sawyers, R. B. \& Williams, P. F. (1997). Reinforcing ethical decision making through corporate culture. Journal of Business Ethics, 16, 855-866.

De-Maria, W. (2005). Whistleblower protection: Is Africa ready? Public Administration and Development, 25(3), 217-226.

Dorasamy, N. \& Pillay, S. (2011a). Whistle blowing: Impediments to effective implementation within the South African public sector. Corporate ownership and Control, 8(3), 196-208.

Dorasamy, N. \& Pillay, S. (2011b). Institutionalising a value enacted dominant organizational culture: An impetus for whistle blowing. Corporate ownership and Control, 8(3), 297-304.

Dryburgh, M. M. (2009). Personal and public implications of whistle blowing: The case of Corcoran State Prison. Public Integration, 11(2), 155-170.

Ethics Resource Centre. (2007). Natural Business Ethics Survey: An inside view of private sector ethics. Arlington, VA: Ethics Resource Centre.

Hellreigel, D., Slocum, J. W. \& Woodman, R. W. (1998). Organizational behaviour, South-Western College Publishing: Ohio.

IOD. (2002). Second King Report on Corporate Governance, Johannesburg: Institute of Directors.

Kaplan, E. (2001). The international emergence of legal protection of whistleblowers. Journal of Public Enquiry, 2, 37-42.

Kouzes, T. M. \& Posner, B. J. (1987). The leadership challenge, San Francisco: Sage.

Lewis, D., Ellis, C. A., Kyprianou, A. \& Homewood, S. (2001). Whistle blowing at work The results of a survey of procedures in further and higher education. Education and the law, 13(3), 215-225.

Miceli, M. P., Near, J. P. \& Dworkin, T. M. (2008). A word to the wise: How managers and policy makers can encourage employees to report wrongdoing. Journal of Business Ethics, 86, 379-396.

Near, J. P. \& Miceli, M. P. (1996). Whistle blowing: Myth and reality. Journal of Management, 22(3), 507526.

Pillay, S., Dorasamy, N. \& Vedran, V. (2012). Exploring whistle blowing intentions in South Africa: A quantitative analysis. African Journal of Business Management, 5(28), 6579-6595.

Pillay, S. \& Dorasamy, N. (2011). Systemic factors moderating effective whistle blowing: an exploratory study into public service organization. African Journal of Business Management, 5(22), 94299439.

Shahinpoor, N. \& Matt, B. F. (2007). The power of one: Dissent and organizational life. Journal of Business Ethics, 7, 37-48.

South Africa. (1996). The Constitution of the Republic of South Africa, Act No 108 of 1996, Pretoria: Government Printer.

South Africa. (2000). The Protected Disclosures Act No 26 of 2000, Pretoria: Government Printer.

Sullivan, J. D. (2009). The moral compass of Companies: Business ethics and corporate governance as anti-corruption tools, Washington: International Finance Corporation.

Van-Vuuren, L. (2008). Ethics and / in organization development". In C.L. Van Tonder and G. Roodt (eds.), Organizational development: Theory and Practice, Van Schaik Publishers: Pretoria.

Werner, A. (2008). Organizational culture, ethics and diversity in a global environment. In A. Werner (ed.), Organizational Behaviour: A contemporary South Africa perspective, Van Schaik: Pretoria.

Zhang, J., Chiu, R. K. \& Wei, L-Q. (2009). Decision-making process of internal whistle blowing behaviour in China: Empirical evidence and implication. Journal of Business Ethics, 88(1), 25-41.

Vinten, G. (1999). Whistle blowing code for educational institutions. International Journal of Educational Management, 13(3), 150-157. 